Teknomekanik

Vol.5, No.1, June 2022, pp. 1 12

e-ISSN: 2621-8720 p-ISSN: 2621-9980

\title{
Development and Implementation of Innovative Technologies That Ensure an Increase in The Extraction of Non-ferrous, Noble, Rare, Rare- Earth Metals
}

\author{
Bagdaulet Kenzhalievich Kenzhaliev*, Kvyatkovskiy Sergey Arkad'yevich, Trebukhov Sergey \\ Anatolyevich, Rinat Anvarbekovich Abdulvaliyev, Aigul Koizhanova, Nessipbay Kuandykovich \\ Tussupbayev, Sergey Vladilenovich Gladyshev and Gulzhaina K. Kassymova
}

Institute Metallurgy and Ore Beneficiation, Satbayev University, Almaty 050010, Republic of Kazakhstan

\begin{tabular}{|c|c|}
\hline Article Info & ABSTRACT \\
\hline $\begin{array}{l}\text { Article history: } \\
\text { Received Dec } 03^{\text {rd }}, 2021 \\
\text { Revised Jan } 25^{\text {th }}, 2022 \\
\text { Accepted Jan } 30^{\text {th }}, 2022\end{array}$ & $\begin{array}{l}\text { The article presents the most innovative technologies developed by Satbayev University, } \\
\text { "Institute of Metallurgy and Ore Beneficiation" JSC (Republic of Kazakhstan, Almaty) in } \\
\text { recent years. The implementation of these works on an industrial scale will lead to } \\
\text { significant economic and environmental effects. The following technologies are } \\
\text { described: synthesis of a new foaming agent for intensification of flotation enrichment of } \\
\text { gold-bearing ores; multicomponent microflotation, which allows to increase the }\end{array}$ \\
\hline Keywords: & $\begin{array}{l}\text { extraction of valuable metals at existing deposits and to develop new, relatively poor and } \\
\text { previously economically unpromising deposits; flotation enrichment of persistent gold- }\end{array}$ \\
\hline $\begin{array}{l}\text { Microflotation, } \\
\text { Enrichment, } \\
\text { Gold, } \\
\text { Copper, } \\
\text { Rare earth metals, } \\
\text { Selenium, } \\
\text { Alumina, } \\
\text { Bauxite }\end{array}$ & $\begin{array}{l}\text { containing ore; contractile pyrometallurgical selection, which allows direct melting of } \\
\text { persistent gold-containing raw materials with the transfer to the gas phase of arsenic, } \\
\text { sulfur and other volatile components, followed by their neutralization and concentration } \\
\text { of gold, silver and other non-ferrous metals in matte melt; continuous conversion of } \\
\text { copper matte in the Vanyukov furnace; processing of liquid metallurgical slags in a } \\
\text { furnace with an electrically heated coke filter; vacuum distillation refining of rough } \\
\text { selenium; extraction of rare earth metals from extraction phosphoric acid obtained during } \\
\text { the processing of phosphorites; processing of high-grade low-quality bauxite. New } \\
\text { technical solutions have been developed in the field of mineral and man-made raw } \\
\text { materials enrichment, metallurgy of non-ferrous, noble, rare and rare earth metals, which } \\
\text { have high economic efficiency and the feasibility of their introduction into production. } \\
\text { The novelty of the presented works is confirmed by the security documents of the Republic } \\
\text { of Kazakhstan. }\end{array}$ \\
\hline
\end{tabular}

Corresponding Author:

Kenzhaliyev B.K.,

Institute Metallurgy and Ore Beneficiation, Satbayev University,

Almaty 050010, Republic of Kazakhstan.

Email: bagdaulet_k@satbayev.university

\section{INTRODUCTION}

The Republic of Kazakhstan is rich in natural resources. Almost all the elements of the Periodic Table are in its depths, most of them in industrial quantities: copper, aluminum, lead, zinc, cadmium, chromium, molybdenum, rhenium, selenium, tellurium, gold and other non-ferrous and rare metals [1]. As a result, at present, metallurgy forms the basis of the Republic's industrial power and its export potential [2]. Involvement in the processing of refractory, complex in composition mineral and technogenic raw materials is an urgent problem for the metallurgical industry around the world. Industrial development of such raw materials in Kazakhstan is limited due to the lack of efficient and cost-effective technologies. At present, the most important problem of the metallurgical industry is the development and implementation of innovative technologies enabling to extract with maximum completeness non-ferrous, rare and rare-earth metals contained in ores, industrial waste and secondary raw materials [3].

In recent years, the Institute has developed innovative and modernized existing technologies for the extraction of non-ferrous, noble, rare and rare-earth metals from mineral, technogenic and secondary raw materials, ensuring an increase in the extraction of non-ferrous, noble, rare, rare-earth metals that are implemented at the production facilities of industrial enterprises of the metallurgical complex of the Republic. Kazakhstan. These works are aimed to increase production parameters and improve the environmental parameters of non-ferrous metallurgy enterprises in general [4].

Journal homepage: http://teknomekanik.ppj.unp.ac.id

DOI: https://doi.org/10.24036/teknomekanik.v5i1.11972 


\section{METHODS}

The performed works are based on comprehensive study methods for the study object and its products on modern analytical equipment by certified methods using chemical, X-ray phase, X-ray fluorescence, atomic absorption and thermal analysis methods, scanning electron microscopy, infrared spectroscopy, Mössbauer spectroscopy, BET method.

\section{RESULTS AND DISCUSSION}

The reserve depletion of primary ores of various metals all over the world forces the involvement of refractory, diffucult and off-balance ores into processing. One of the main economic criteria for the profitability of a deposit is the preliminary ore preparation for metallurgical processing, the so-called beneficiation process. Developed a technology for the synthesis of a new foaming agent for the intensification of flotation concentration of gold-bearing ores [5]. The use of fusel oil as a feedstock that is an alcohol production waste in Kazakhstan during the synthesis of composite xanthate, Aeroflot and a foaming agent, significantly reduces the cost of reagents and significantly improves their flotation characteristics compared to the base ones. Experimental tests of the processing technology for gold-bearing finely disseminated ore with the use of a modified collector were performed; a gold-bearing concentrate was obtained with a gold content of $38.0 \mathrm{~g} / \mathrm{t}$ with an extraction of $88.8 \%$ [6]. The use of a new collector increases gold recovery by $4.67 \%$. The gold content in the flotation tailings is reduced from 0.4 to $0.3 \mathrm{~g} / \mathrm{t}$. The proposed composite collectors obtained from fusel oil are multicomponent, effective and cheap. The uniqueness of the proposed composite collectors is in the fact that, unlike their counterparts, they are cheap, cost-effective reagents. However, for the complete extraction of valuable sludge minerals from refractory finely disseminated ores and technogenic raw materials, it is possible to achieve with the combined use of domestic composite reagents and the "multicomponent microflotation" method that is performed with a turboflotation apparatus [7].

The introduction of the proposed "multicomponent microflotation" technology at the mining and metallurgical complex enterprises will significantly increase the extraction of valuable metals at existing deposits, develop new relatively poor and previously economically unpromising deposits [8]. Solving the problem of beneficiation of finely dispersed minerals will increase the competitiveness of products in the world market, take a leading position in the promotion of innovative technologies both within the country and abroad. The flotation concentration technology for refractory gold-bearing ore has been developed, the leaching process for gravity and flotation concentrates in the presence of an oxidizer to open gold has been studied $[9,10]$. The technological scheme of gold extraction using the method of flotation enrichment of persistent gold-bearing ore is shown in Figure 1. The results of the staged flotation ore concentration show the possibility to obtain gold tailings of flotation with a gold grade of less than $0.7 \mathrm{~g} / \mathrm{t}$. The gold extraction into a combined concentrate (gravity-flotation) with a gold content of $49.7 \mathrm{~g} / \mathrm{t}$ is $88.88 \%$. For the first time, the effect of a modified oxidant (a mixture of calcium hypochlorite and trichloroisocyanuric acid) on the leaching process of gravity concentrate with the achievement of a gold recovery rate of $76.9 \%$ was studied; from flotation concentrate $-68.8 \%$ that is $5 \%$ higher compared to the base [11].

Currently, there are no technologies to process refractory gold ores containing carbon and arsenic with satisfactory technical and economic parameters. The technology of contractile pyrometallurgical selection provides (CPS-process) [12] for direct smelting of refractory gold-bearing raw materials with the transfer of arsenic, sulfur and other volatile components into the gas phase, followed by their neutralization and concentration of gold, silver and other non-ferrous metals in the matte melt, the yield of which will be 10-15\% of the charge weight [13]. Industrial tests on the PV-1 furnace of the Balkhash copper-smelting plant were performed in two stages, the results of which are shown in Table 1. Charge capacity at the first stage was 80 $\mathrm{t} / \mathrm{h}$. Chemical composition of the stack is as follows, wt. \%: $18.34 \mathrm{Cu}, 25.86 \mathrm{Fe}, 28.78 \mathrm{~S}, 11.71 \mathrm{SiO}_{2}, 1.1 \mathrm{CaO}$, $1.6 \mathrm{~Pb}, 2.0 \mathrm{Zn}$. The reducing agent, which was used as shungite, was $1 \%$ of the stack weight. 326 tons of quartz flux were additionally recycled during stack processing. Chemical composition of the stack including quartz flux is as follows, wt. \%: $18.13 \mathrm{Cu}, 25.15 \mathrm{Fe}, 28.29 \mathrm{~S}, 13.12 \mathrm{SiO}_{2}, 1.0 \mathrm{CaO}, 1.5 \mathrm{~Pb}, 1.9 \mathrm{Zn}$.

The following extraction of metals into matte is achieved, in\%: gold - 95-98, silver - 85-90, copper - 8590. Matte can be processed in copper smelters with existing technology. At the same time, the end-to-end extraction of noble metals is $20-30 \%$ higher than the extraction parameters of these metals from refractory gold ores achieved in industry. The main condition for the process efficiency is the gold content in the starting materials not less than $5 \mathrm{~g} / \mathrm{t}$. The main disadvantage of the world's most widespread technology intended to process copper mattes in Peirce-Smith converters is the process periodicity [14,15]. At the same time, it is difficult to use gases that are not constant in terms of the sulfur dioxide content. The continuous converting technology for copper mattes in the Vanyukov furnace enables to obtain constant composition gases rich in sulfur dioxide, blister copper and a minimum volume of copper-poor converter slags [16].

The use of continuous converting eliminates the periodicity of the blister copper production process, enables to use oxygen-enriched blast, to obtain a stable flow of sour gas of constant composition, to reduce

Journal homepage: http://teknomekanik.ppj.unp.ac.id

DOI: https://doi.org/10.24036/teknomekanik.v5i1.11972 
sulfur dioxide emissions to the atmosphere to a minimum, to increase the degree of sulfur utilization that contributes to an improvement in the environmental situation. It is recommended for use in non-ferrous metallurgy enterprises with a copper matte conversion process [17]. Figure 2 shows a diagram of a two-zone Vanyukov furnace (melting in a liquid bath). Main parameters of the two-zone PV furnace: - matte consumption, $\mathrm{t} / \mathrm{h}$ - 69-96; - coal consumption, $\mathrm{t} / \mathrm{h}$ - 0.5-2.5; - flux consumption, $\mathrm{t} / \mathrm{h}$ - 1.0-7.5; - oxygen consumption, $\mathrm{nm}^{3}$ / h - 12000-24000; - air consumption, $\mathrm{nm}^{3} / \mathrm{h}$ - 3000-10000; - specific oxygen consumption, $\mathrm{nm}^{3} / \mathrm{t}$ - 160-295; - temperature in the reduction zone, ${ }^{\circ} \mathrm{C}-1280-1300$; - matte temperature, ${ }^{\circ} \mathrm{C}-1125-1250$; - outlet gas temperature, ${ }^{\circ} \mathrm{C}-320-565$; - bath height, $\mathrm{mm}$ - 2250-2400; - width of the recovery zone, mm 2200; - length of the recovery zone, $\mathrm{mm}-6000$; - Cu content in matte, $\%$ - 43.5-63.6; - Cu content in slag, \% $0.4-0.8 ;-\mathrm{SiO}_{2}$ content in slag, \% - 30.0-32.8. The existing methods of depletion of non-ferrous metallurgy slags do not provide a sufficiently complete extraction of metals from slags. The processing technology for liquid metallurgical slag in a furnace with an electrically heated coke oven filter enables to obtain a metallized phase that concentrates iron, copper and precious metals; fumes containing lead and zinc; slags completely dumping for non-ferrous metals, suitable for the production of building materials [18]. Figure 3 shows a diagram of a combined unit, including a Vanyukov smelting furnace and a coke filter for slag processing $\%-0.4-0.8 ;-\mathrm{SiO}_{2}$ content in slag, \% - 30.0-32.8.

The heating of the coke filter is performed in the most economical way in an electric furnace with electric energy that enables to significantly reduce the consumption of scarce coke used in this case as a reagent, and to obtain a minimum amount of waste gases with a significant reduction in the cost of cleaning them. The copper extraction into an iron-copper alloy was $91.9 \%$, iron about 70\%, and lead and zinc into sublimates - 94 and $88 \%$, respectively. Average coke consumption is $5-7 \%$ of the processed slag mass. The average specific power consumption is $250 \mathrm{kWh} / \mathrm{t}$ of liquid slag. It is recommended for use in non-ferrous metallurgy enterprises. When autogenous technologies are used to smelt sulphide raw materials, slags are formed that require separate processing for additional recovery of non-ferrous metals [19]. The main principles of the continuous smelting process for copper sulphide concentrates with reduction finishing of slags in the tail zone of the PV furnace (Vanyukov melting furnace) have been developed to obtain slags with a minimum copper content of $0.5-0.7 \%$ [20]. Slag reduction is performed by adding a carbon-containing reductant (coal, coke, shungite, etc.) to the reduction zone of the furnace. This technology enables to use the tail end of the PV furnace to reduce slag processing by installing a baffle dividing the furnace into an oxidizing smelting zone and a reduction zone, where magnetite and partially zinc and lead are reduced enablig to obtain slags poor in copper and lead-zinc sublimates. Basic parameters of continuous matte conversion furnace: - matte output, $\mathrm{t} / \mathrm{h}-55$ 65 ; - copper content in matte, \% - 55-60; - matte humidity, max, \% - 6; - dimensions of melting zone in tuyeres area: length, width $-9 \times 2$, area, $\mathrm{m}^{2}-18$; - height of tuyeres installation from bed in melting zone, mm - 1600; - number of tuyeres in melting zone, pcs. - Quantity of oxygen-containing blast for one lance, $\mathrm{nm}^{3} / \mathrm{h} \mathrm{-} 1000$; Blast volume per $1 \mathrm{t}$ of matte, $\mathrm{nm}^{3} / \mathrm{h}-220$. It is recommended for use in non-ferrous metallurgy enterprises. Recommended for use in non-ferrous metallurgy enterprises.

Table 1: Basic technological parameters of industrial tests of the CPS-process

\begin{tabular}{lccc}
\hline \multicolumn{1}{c}{ Parameters } & Unit of measure. & Stage I & Stage II \\
\cline { 3 - 4 } Content in the charge & & & \\
$\mathrm{Cu}$ & $\%$ & $19.3-18.6$ & $18.6-18.9$ \\
$\mathrm{~S}$ & $\%$ & $30.2-28.9$ & $28.5-29.3$ \\
$\mathrm{SiO}_{2}$ & $\%$ & $11.5-11.7$ & $12.6-12,9$ \\
Duration of tests & $\mathrm{h}$ & 125 & 109 \\
Charge consumption & $\mathrm{t} / \mathrm{h}$ & $65-101$ & $69-96$ \\
Coal consumption & $\mathrm{t} / \mathrm{h}$ & $0-2.5$ & $0.5-1.6$ \\
Flux consumption & $\mathrm{t} / \mathrm{h}$ & $0-7.5$ & 0 \\
Oxygen CHB-1 & ths. $\mathrm{nm}^{3}$ & $13706-24197$ & $12782-17757$ \\
Air CHB-1 & ths. $\mathrm{nm}{ }^{3}$ & $125-8671$ & $5940-10212$ \\
Specific oxygen consumption & $\mathrm{nm}{ }^{3} / \mathrm{t}$ & $166-295$ & $174-260$ \\
Temperature in the siphon & ${ }^{\circ} \mathrm{C}$ & $1170-1271$ & $1165-1269$ \\
Matte temperature & ${ }^{\circ} \mathrm{C}$ & $1130-1250$ & $1125-1203$ \\
Heat transfer by caissons & thousand kJ / h & $24576-41688$ & $22939,3-28295,17$ \\
RF Steam Removal & $\mathrm{t} / \mathrm{h}$ & $12-24$ & $13-26$ \\
Gas temperature on the RF collar & ${ }^{\circ} \mathrm{C}$ & $921-1159$ & $987-1113$ \\
Gas temperature at the outlet of RF & ${ }^{\circ} \mathrm{C}$ & $321-551$ & $383-565$ \\
Total bath height & $\mathrm{mm}$ & $2250-2400$ & $2250-2400$ \\
Foam height & $\mathrm{mm}$ & $0-50$ & $0-100$ \\
Recorded overshoots / blowouts & $\mathrm{pcs}$. & - & $6 / 3$ \\
& & &
\end{tabular}

Journal homepage: http://teknomekanik.ppj.unp.ac.id

DOI: https://doi.org/10.24036/teknomekanik.v5i1.11972 
Copper content in matte

Copper content in slag

$\%$

$\%$

$\%$
$43.3-59.6$

$0.56-0.90$

26.4-32.6
$49.5-63.6$

$0.6-1.0$

$28.7-32.8$

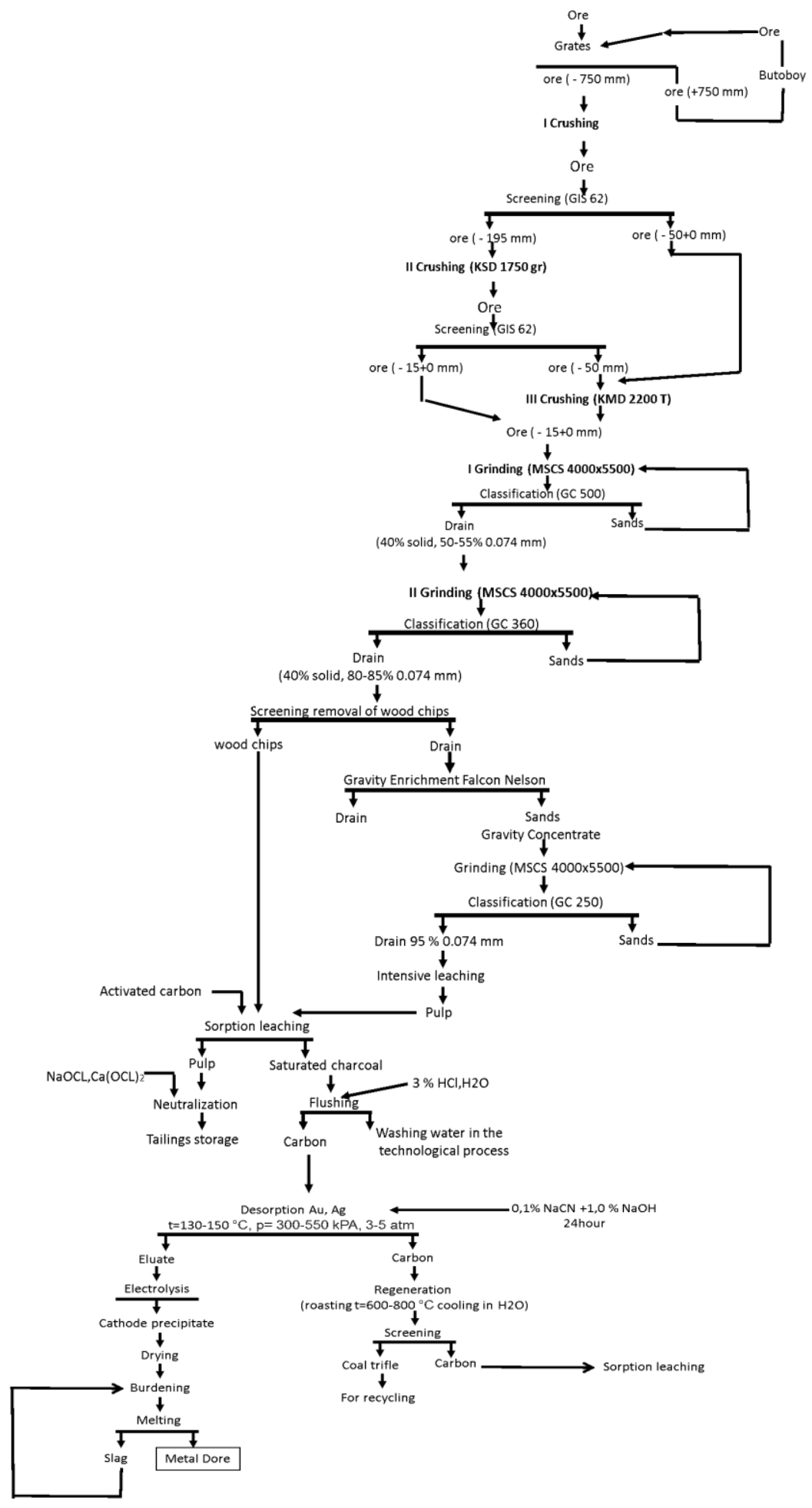

Figure 1 : Process flow of gold extraction from Sekisovskoye deposit ore 


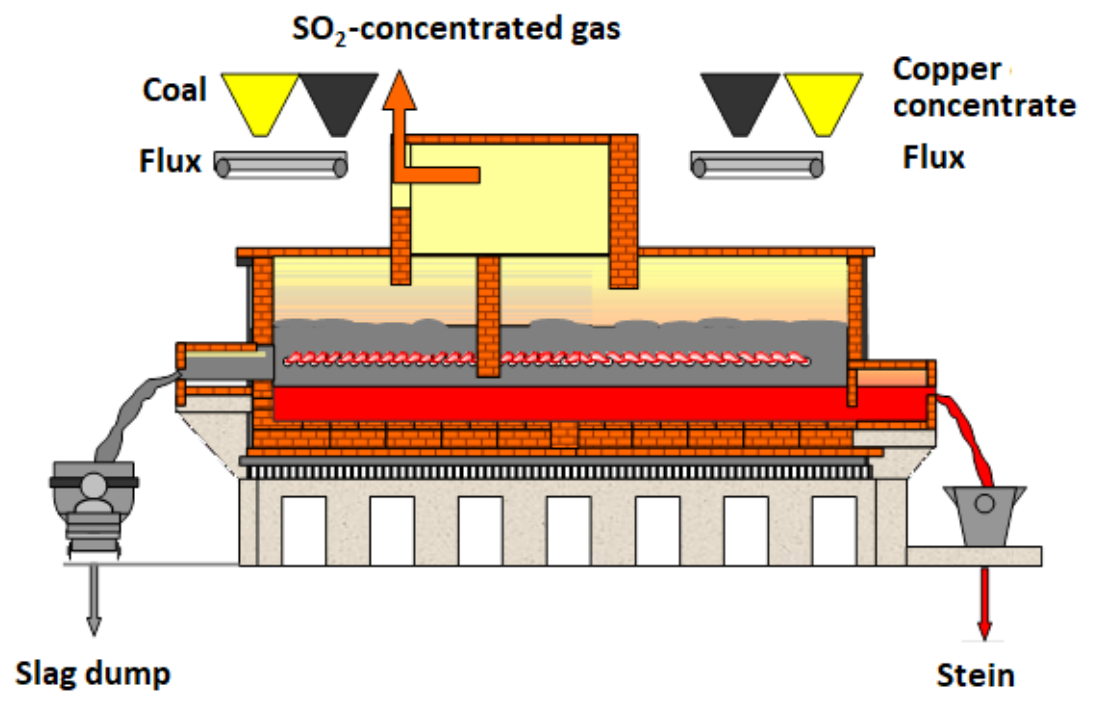

Figure 2 : A diagram of a two-zone Vanyukov furnace (melting in a liquid bath)

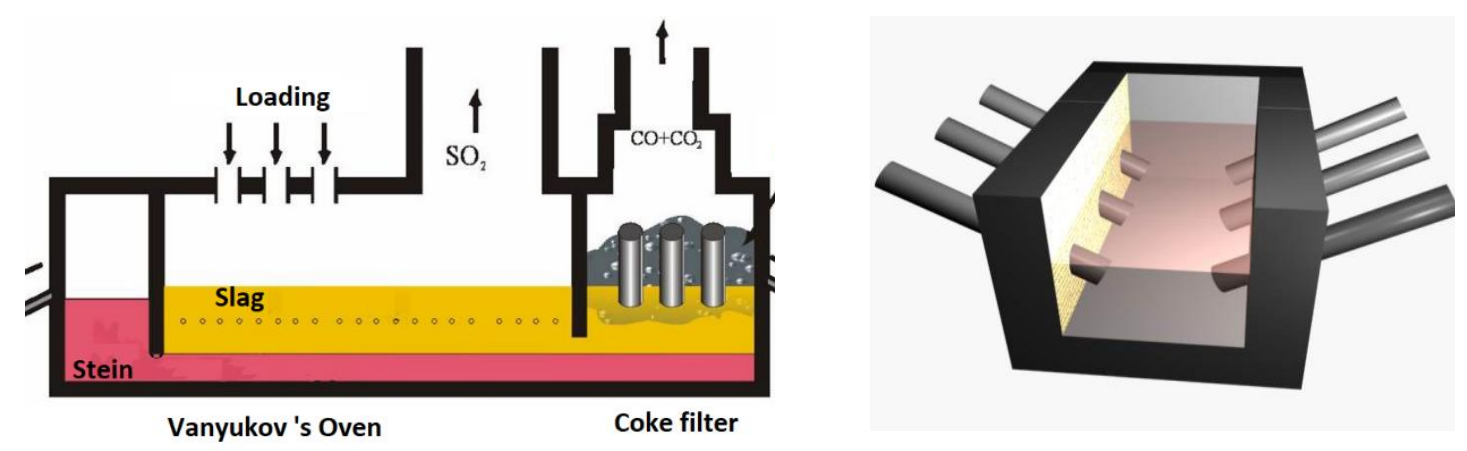

Figure 3 : Schematic diagram of a combined unit including a Vanyukov melting furnace and a coke filter for slag processing

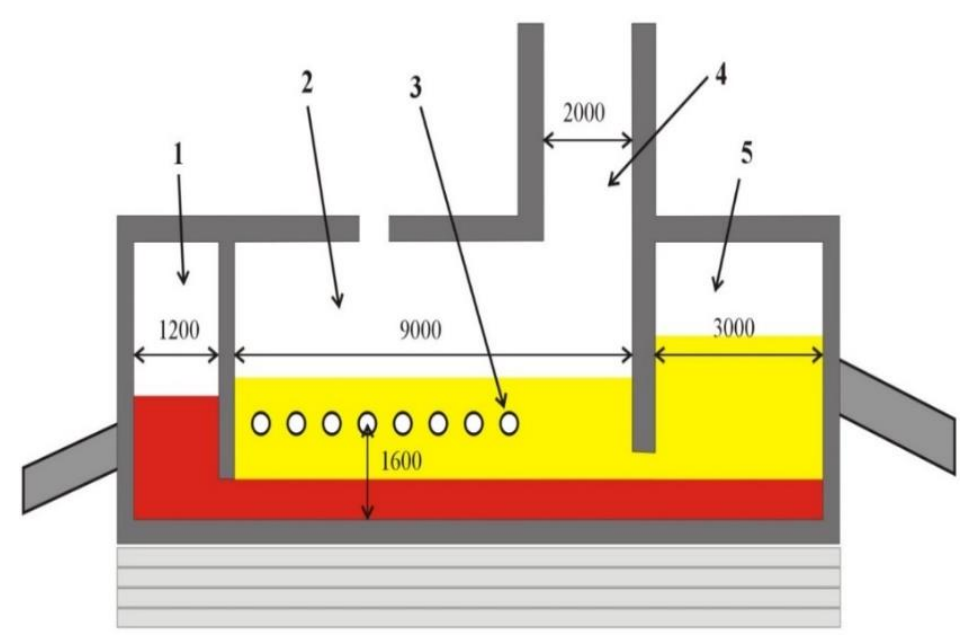

1 - copper blister siphon; 2 - melting zone; 3 - tuyeres; 4 - gas duct; 5 - slag siphon.

Figure 4 : Schematic diagram of Vanyukov furnace for continuous conversion of copper matte 
Table 2 : Material balance of selenium distribution by vacuum distillation products

\begin{tabular}{|c|c|c|c|c|c|}
\hline \multirow[t]{2}{*}{ Products name } & \multirow{2}{*}{$\begin{array}{c}\text { Dry weight, } \\
\text { kg }\end{array}$} & \multirow{2}{*}{$\begin{array}{c}\text { Output, } \\
\%\end{array}$} & \multicolumn{2}{|c|}{ Se content } & \multirow{2}{*}{$\begin{array}{c}\text { Distribution } \\
\%\end{array}$} \\
\hline & & & $\%$ & $\mathrm{~kg}$ & \\
\hline \multicolumn{6}{|l|}{ Loaded: } \\
\hline Smelted Se & 10.94 & 100.00 & 95.61 & 10.57 & 100.00 \\
\hline Received: & & & & & \\
\hline Refined Se & 10.51 & 96.07 & 99.54 & 10.46 & 98.96 \\
\hline Dry residue & 0.08 & 0.73 & - & - & - \\
\hline Total received & 10.59 & 96.80 & - & 10.46 & 98.96 \\
\hline Non-viscous: & -0.35 & -3.20 & - & -0.11 & -1.04 \\
\hline
\end{tabular}

Copper electrolyte production slimes containing selenium are formed in the process to obtain copper. We have developed technologies to extract elemental selenium from this middling product with subsequent refining by vacuum distillation [21,22]. An industrial prototype of a vacuum distillation unit was made, with a capacity of up to 2.0 tons of refined selenium per month, where large-scale tests of the technology were performed [23]. Table 2 shows the material balance of the distribution of selenium by the products of vacuum distillation processing of crude selenium obtained as a result of processing copper electrolyte sludge in the Kaldo furnace.

$\mathrm{X}$-ray fluorescence analysis in ingots of refined selenium determined the following content of elements, wt. \%: 99.543 - Se; 0.217 - O; 0.003 - S; 0.003 - Pb; 0.021 - Mg; 0.007 - Ni;0.005 - Al; 0.122 - Te; 0.005 - Cl; 0.003 - Si; $0.031-\mathrm{Sb} ; 0.033-\mathrm{Cr} ; 0.002-\mathrm{Cu} ; 0.005-\mathrm{Fe}$. The output of refined selenium was $96.07 \%$. Selenium was converted to raffinate by $98.96 \%$. Selenium was not found in the bulk residue from the distillation, while the silver content was 2.05 wt. \%. The increased iron content in bauxite rsults in serious sintering problems. Therefore, it is required to preliminarily separate ferruginous compounds as much as possible - iron sands from the bauxite bulk. The processing of ferruginous sands is an important practical task the solution of which will increase the profitability of the existing alumina production. The technology developed for processing ferruginous sands includes the production of cast iron, concentrates of rare metals, rare earth elements, red and black pigments and titanium dioxide [24,25]. The Process flow for the processing of ferruginous sands of alumina production is shown in Figure 5.

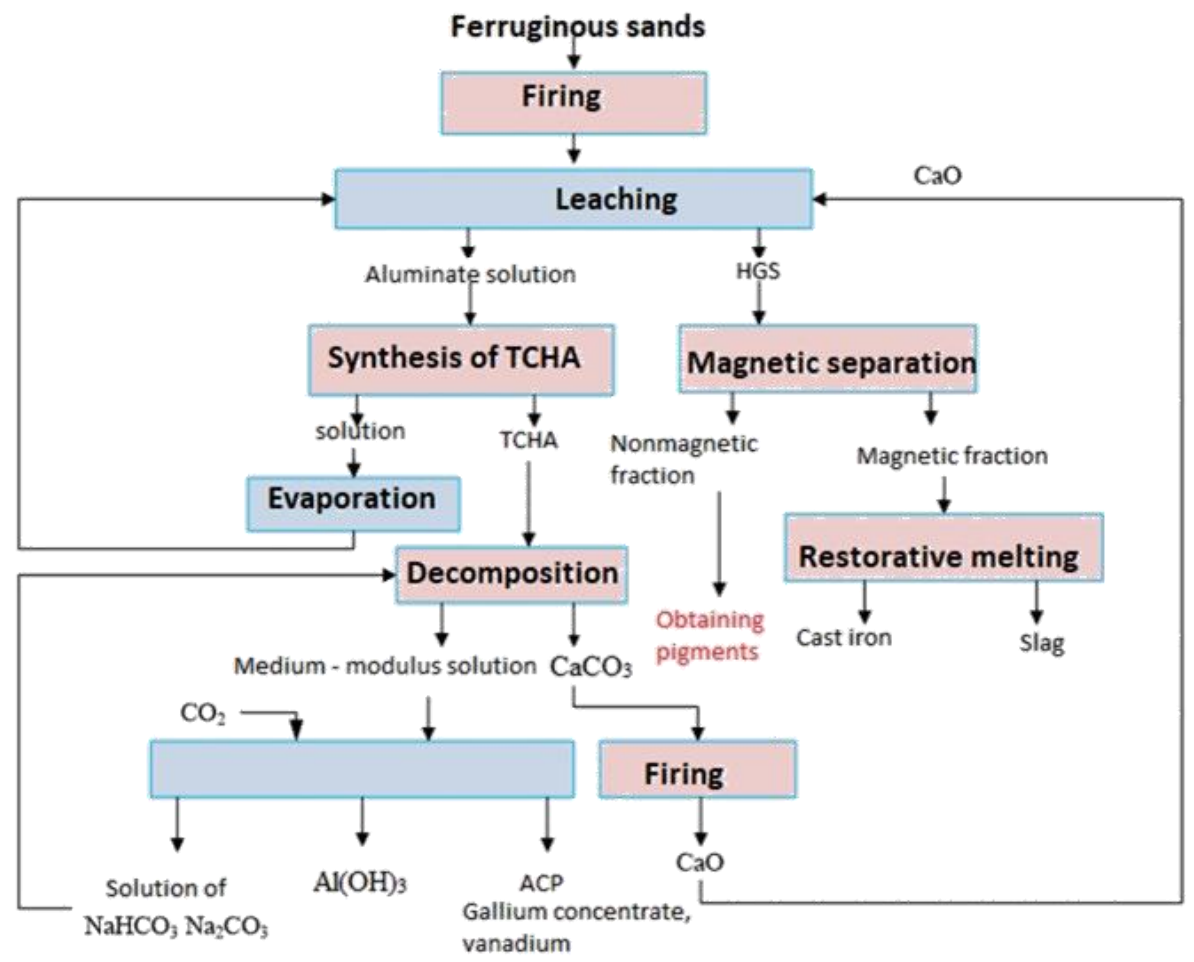

Figure 5 : Process flow of processing of ferruginous sands of alumina production 
Concentrates of rare metals - gallium and vanadium of the composition, wt. \%: $30.0 \mathrm{Al}_{2} \mathrm{O}_{3}, 0.32 \mathrm{Ga}_{2} \mathrm{O}_{3}$ and $4.85 \mathrm{~V}_{2} \mathrm{O}_{5}$ - were obtained from the aluminate leaching solution. As a result of the reduction melting of the ferrous sand leaching cake at a temperature of $1450^{\circ} \mathrm{C}$, cast iron and unmetallic slag were obtained. The iron yield in cast iron was $99.4 \%$. A concentrate containing $20.74 \%$ of REE and titanium dioxide with a content of $61.8 \% \mathrm{TiO}_{2}$ was obtained from unmetallic cast iron slag. As a result of the research, the Technological Regulations for the integrated processing of ferruginous sands of alumina production and a preliminary business plan were developed. The importance to solve the problem of use of the products of chromium ore dressing in waste processing is associated not only with the environment but also with the need to increase the chromium production. The enterprise engaged in the extraction and beneficiation of chromium raw materials in Kazakhstan is Donskoy MPP. During the operation of the concentrating factories, the plant has stockpiled about 15 million tons of sludge tailings, the loss of $\mathrm{Cr}_{2} \mathrm{O}_{3}$ by the beneficiation technology is up to $25.5 \%$. The known methods of utilization of ferrochrome production middlings and waste products do not enable to extract accompanying valuable components - rare metals and rare earth elements - along the way [26]. A technological scheme has been developed, shown in Figure 6, for the complex processing of chromium waste, including leaching in a solution of ammonium hydrosulfate, to obtain a concentrate of rare metals gallium and vanadium, a concentrate of rare earth elements with a content of $21.58 \%$ and a chromium concentrate with a $\mathrm{Cr}_{2} \mathrm{O}_{3}$ content of $59.1 \%$ [27].

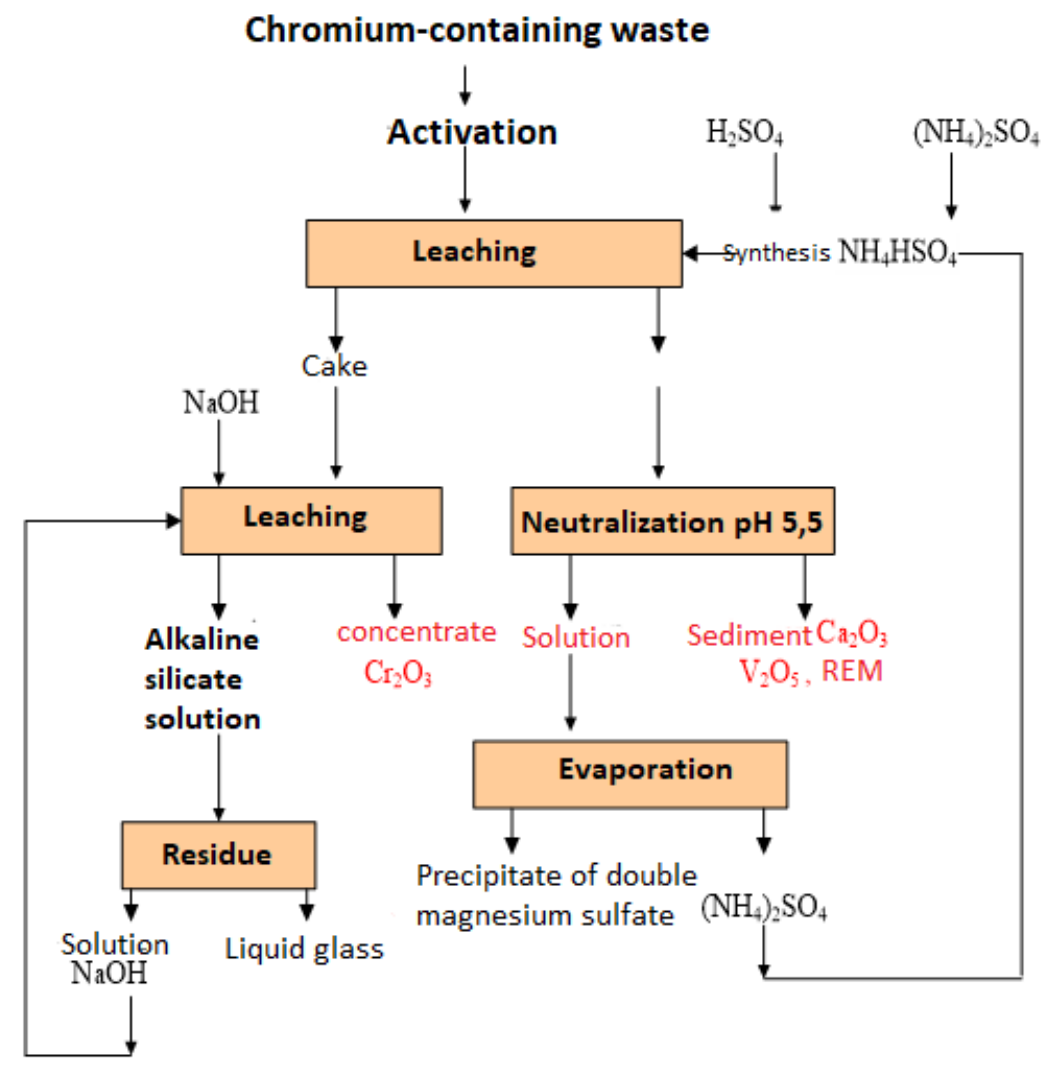

Figure 6 : Process flow of complex processing of chrome waste

High technological indicators of the technology for obtaining concentrate of rare metals, gallium and vanadium from wet gas purification sludge of ferrochrome production are confirmed by experimental tests. The following rare metal concentrate composition, wt. \% was obtained: $30.1 \mathrm{Al}_{2} \mathrm{O}_{3} ; 25.48 \mathrm{SiO}_{2} ; 4.83 \mathrm{~V}_{2} \mathrm{O}_{5}$; $1.01 \mathrm{Ga}_{2} \mathrm{O}_{3}$. Extraction in the concentrate was, $\%: 40.1 \mathrm{Ga}_{2} \mathrm{O}_{3} ; 38.1 \mathrm{~V}_{2} \mathrm{O}_{5}$; REE concentrate composition, wt. $\%: 23.7 \mathrm{MgO} ; 0.3 \mathrm{Al}_{2} \mathrm{O}_{3} ; 10.8 \mathrm{Fe}_{2} \mathrm{O}_{3} ; 21.58 \sum \mathrm{REE}$, the REE concentrate yield was $1.395 \%$ of the initial charge mass [28]. A technology has been developed for the extraction of rare earth metals from extraction phosphoric acid obtained by processing phosphorites $[28,29]$.

Technological modes of desorption for rare-earth metals from a cation exchanger to obtain a concentrate of rare-earth metals have been worked out. Various desorbing solutions have been tested: ammonium chloride; ammonium sulfate; a mixture of nitric acid with ammonium nitrate; a mixture of hydrochloric acid with ammonium chloride; a mixture of sulfuric acid with ammonium sulfate. The optimal conditions for the 
desorption of REM from the Purosorb 140 cation exchanger have been determined: the precipitation parameters of REM salts have been determined and a conditioned 92.22\% REM concentrate has been obtained. Table 3 shows a material balance of REM extraction from phosphoric acid extraction.

Experimental tests of the developed technology of REM extraction from unpaired dihydrate EPA resulted in determination of sorption and desorption parameters, modes of selective precipitation of iron and REM. Oxide concentrate with REM content of $97 \%$ was obtained [30,31]. When bauxites are processed in Kazakhstan, along with alumina, only gallium is extracted in an amount of 7-8\% of the input. Other rare metals that make up their composition are of industrial interest but their behavior in the processes of alumina production has been insufficiently studied [32].

On the basis of existing alumina production operation studies for processing high-ferrous bauxites of Aluminum of Kazakhstan JSC, intermediate products containing rare metals - recycled soda, ferrous sands and red mud were selected and a technological scheme for their joint processing was developed to obtain a collective concentrate with a content of $0.4 \% \mathrm{Ga}$ and $14.31 \% \mathrm{~V}_{2} \mathrm{O}_{5}$. Vanadium pentoxide was obtained with a content $\mathrm{V}_{2} \mathrm{O}_{5} 99,1 \%$ with the help of ammonia technology. An electrolysis method on a rotating galvanized cathode has been developed to obtain metallic gallium. The extraction during electrolysis was $95.9 \%$ with an electric power consumption of $87.7 \mathrm{kWh} / \mathrm{kg}$ gallium. A gradual decrease in the high-quality bauxite production, high operating costs and energy intensity of the methods used for the extraction and processing of raw materials, in combination with their environmentally unfavorable impact, are, in aggregate, an objective basis to use low-quality aluminum-containing raw materials in the production [33]. Alumina production in the Republic of Kazakhstan with the help of Bayer-sintering technology becomes less profitable and competitive and requires serious modernization.

Table 3 : Material balance of REM extraction from phosphoric acid extraction

\begin{tabular}{|c|c|c|c|c|c|c|c|c|}
\hline \multirow[b]{2}{*}{ Operation } & \multirow[b]{2}{*}{ Product name } & \multirow{2}{*}{$\begin{array}{l}\text { Quantity } \\
\mathrm{dm}^{3}(\mathrm{~g})\end{array}$} & \multicolumn{2}{|c|}{$\mathrm{CaO}$} & \multicolumn{2}{|c|}{$\mathrm{Fe}_{2} \mathrm{O}_{3}$} & \multicolumn{2}{|c|}{$\mathrm{REM}_{\mathrm{ox}}$} \\
\hline & & & $\mathrm{g}$ & $\begin{array}{c}\%, \\
\mathrm{~g} / \mathrm{dm}^{3}\end{array}$ & $\mathrm{~g}$ & $\begin{array}{c}\%, \\
\mathrm{~g} / \mathrm{dm}^{3}\end{array}$ & $\mathrm{~g}$ & $\begin{array}{c}\% \\
\mathrm{~g} / \mathrm{dm}^{3}\end{array}$ \\
\hline \multirow{2}{*}{ Products } & $\begin{array}{l}\text { EPA(extraction } \\
\text { phosphoric acid) }\end{array}$ & 43.76 & 196 & 4.48 & 436.17 & 9.97 & 23.85 & 0.545 \\
\hline & $\begin{array}{c}\text { Purosorb SAC } \\
140\end{array}$ & 1411 & & & & & & \\
\hline \multirow{2}{*}{ Sorption } & $\begin{array}{c}\text { Purosorb SAC } \\
140\end{array}$ & 1411 & 28.0 & 1.99 & 48.17 & 3.41 & 10.02 & 0.71 \\
\hline & EPA & 43.76 & 168.0 & 3.84 & 388 & 8.87 & 13.83 & 0.316 \\
\hline \multirow{2}{*}{ Desorption } & $\begin{array}{c}\text { Purosorb SAC } \\
140\end{array}$ & 1411 & 27.86 & 1.97 & 45.97 & 3.25 & 0.24 & 0.017 \\
\hline & Strippant & 1.2 & 0.14 & 0.12 & 2.2 & 1.84 & 9.78 & 8.15 \\
\hline \multirow{3}{*}{$\begin{array}{l}\text { Sedimentation } \\
\text { stage } 1\end{array}$} & $\mathrm{Na}_{2} \mathrm{CO}_{3}$ & 40 & & & & & & \\
\hline & Sediment & 4.19 & 0.07 & 1.67 & 2.17 & 51.8 & 0.04 & 0.95 \\
\hline & Solution & 1.2 & 0.06 & 0.05 & 0.03 & 0.04 & 9.74 & 8.11 \\
\hline \multirow{3}{*}{$\begin{array}{l}\text { Sedimentation } \\
\text { stage } 2\end{array}$} & $\mathrm{Na}_{2} \mathrm{CO}_{3}$ & 60 & & & & & & \\
\hline & Sediment & 12.05 & 0.05 & 0.41 & 0.02 & 0.16 & 9.73 & 80.83 \\
\hline & Solution & 1.17 & 0.01 & 0.01 & 0.01 & 0.01 & 0.01 & 0.01 \\
\hline Calcination & Sediment & 10.0 & 0.05 & 0.5 & 0.02 & 0.2 & 9.73 & 97.3 \\
\hline
\end{tabular}

The developed Bayer-hydro-garnet technology enables to solve the problem of high-iron low-quality bauxite processing with minimization of alkali and alumina losses, reduction of electricity consumption and material costs $[34,35,36]$. The technological scheme of the Bayer-Hydrogranate technology is shown in Figure 7 . 
1

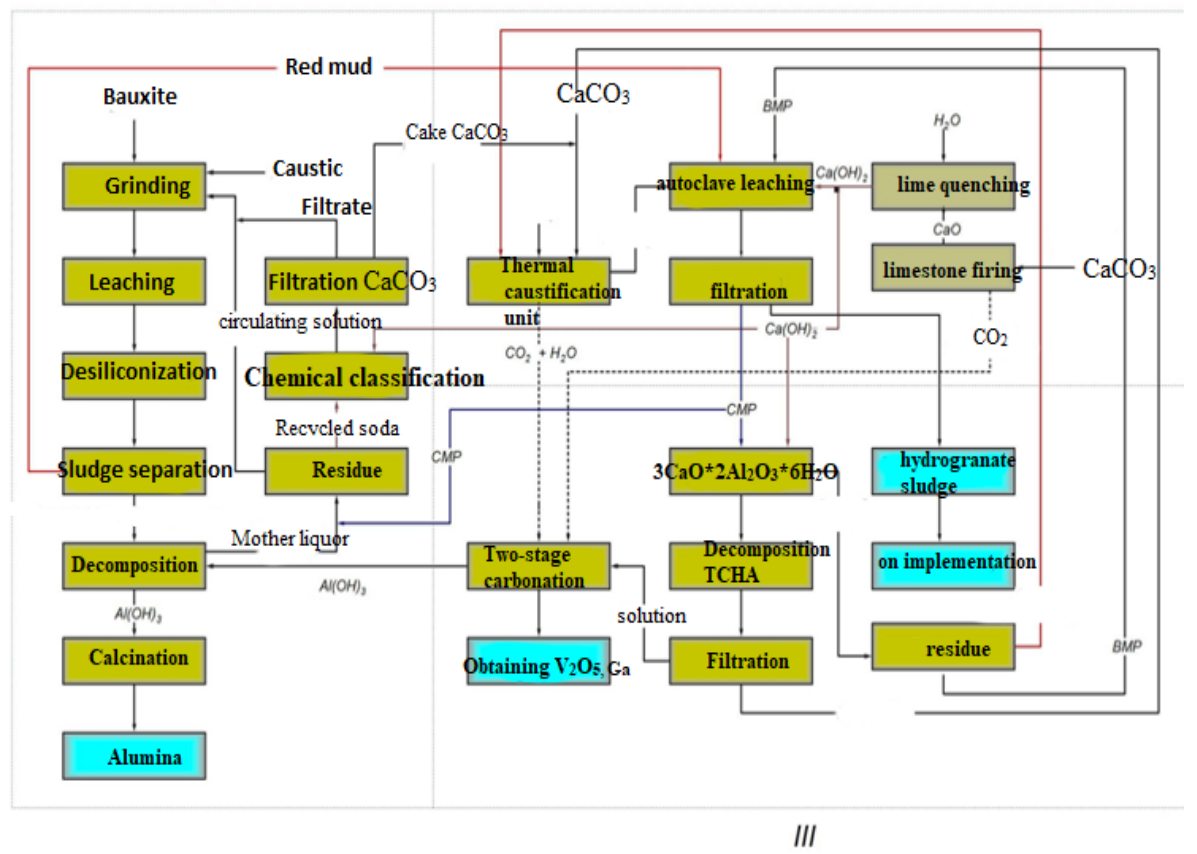

I - Bayer branch block;

II - unit for hydro-garnet processing of red mud,

III - unit for conversion of alkaline-aluminate solutions

Figure 7 : Hydro-garnet technology of ferrous bauxite processing

The technology includes the red mud processing from the Bayer branch using the hydro-garnet technology and the conversion of aluminate solutions to obtain aluminum hydroxide. The use of hydro-garnet processing made it possible to extract an additional $10.23 \%$ of alumina. The technology includes the processing of red mud of the Bayer branch using the hydro-garnet technology and the conversion of aluminate solutions to obtain aluminum hydroxide. The use of hydro-garnet processing made it possible to extract an additional $10.23 \%$ of alumina. The possibility of obtaining pig iron from hydro-garnet sludge by means of reduction melting at a temperature of $1650{ }^{\circ} \mathrm{C}$ has been determined. The pig iron yield was $39.5 \%$ of the weight of the initial charge [37].

\section{CONCLUSION}

Thus, the technologies presented in the work have passed laboratory and pilot tests, some of them have been tested on a pilot scale. The conducted studies correspond to the level of research conducted in the world in the field of metallurgy and many, due to the specificity of Kazakhstan raw materials, are original. Thus, for the first time, the main design parameters of the two-zone Vanyukov furnace were determined, the technology of selenium extraction from industrial products of refining production was developed, effective modified flotation reagents were proposed to increase the extraction of copper and molybdenum into coppermolybdenum concentrate. It is shown that the use of an oxidizer (a mixture of calcium hypochlorite and trichloroisocyanuric acid) helps to increase the extraction of gold. Unique technologies have been developed for processing ferrous sands of alumina production to produce cast iron, concentrates of rare metals, rare earth elements and titanium dioxide and to obtain gallium and vanadium concentrate from the tailings of chromite ore enrichment. The parameters of desorption of rare earth metals from Purosorb 140 ionite saturated with REM from extraction phosphoric acid were determined. A unique Bayer-hydrogranate technology for processing high-iron bauxite has been developed and a pilot plant with a capacity of $50 \mathrm{~kg} / \mathrm{hour}$ for alumina, which has no analogues in the world, has been created.

\section{ACKNOWLEDGEMENTS}

The presented article presents the materials of the works of Satbayev University, "Institute of Metallurgy and Ore Beneficiation" JSC.

Journal homepage: http://teknomekanik.ppj.unp.ac.id

DOI: https://doi.org/10.24036/teknomekanik.v5i1.11972 


\section{REFERENCES}

[1] https://nedra.kz/article/prirodnye-resursy-kazahstana-i-ih-razmeshenie (date of treatment 09/10/2021).

[2] Alimbaev T., Mazhitova Z., Beksultanova C., Tentigulkyzy N. Activities of mining and metallurgical industry enterprises of the Republic of Kazakhstan: Environmental problems and possible solutions / E3S Web of Conferences. -175. - 2020. - 14019

[3] Kunanbaeva K., Argyngazinov A., Madiiarova D., Sagyndykova R. Development of integration processes in the mining and metals sector in Russia and Kazakhstan under business transformation / E3S Web of Conferences. - 210, - 2020. - 13032.

[4] Kenzhaliyev B.K. Innovative technologies providing enhancement of nonferrous, precious, rare and rare earth metals extraction // Kompleksnoe ispol'zovanie mineral'nogo syr'a. - №3. - 2019. - P. 64-75. https://doi.org/10.31643/2019/6445.30

[5] Rulyov N., Tussupbayev N., Turusbekov D., Semushkina L., Kaldybayeva Z. Effect of microbubbles as flotation carriers on finesulphide ore beneficiation //Transactions of the Institutions of Mining and Metallurgy, Section C: Mineral Processing and Extractive Metallurgy. - 2018. - Vol.127. - N.3. - P. 133139. https://doi.org/10.1080/03719553.2017.1351067

[6] Tussupbayev N. Composite aeroflots for intensification of flotation of gold-bearing ores / International scientific and practical conference "Effective technologies for the production of nonferrous, rare and precious metals". Almaty, 25-27 september 2018. - P.95-97.

[7] Tussupbayev N. K., Rulyov N. N., Kravtchenco O.V. Microbubble augmented flotation of ultrafine chalcopyrite from quartz mixtures // Mineral Processing and Extractive Metallurgy. - 2016. - V.125. № 1. - P. 5-9. https://doi.org/10.1179/1743285515Y.0000000014

[8] Turysbekov D.K., Rulev N.N., Semushkina L.V., Narbekova S.M. Increasing the efficiency of enrichment of gold-bearing ore by using combined microflotation // Non-ferrous metals. - № 8. - 2018. - P.13-18. https://doi.org/10.17580/tsm.2018.08.02

[9] Abdykirova G.Zh., Kenzhaliev B.K., Kozhanova A.K., Magomedov D.R., Study of the enrichment of low-sulfide gold quartz ore // Ore enrichment. - 2020. - № 3. - P.14-18. https://doi.org/10.17580/or.2020.03.03

[10] Kenzhaliyev B.K., Koizhanova A.K., Magomedov D.R., Kamalov E.M., Erdenova M.B., Abdyldaev N.N. A study of the biohydrometallurgical method for extracting gold from flotation tailings // Metalurgija - 2020. - V. 59. - №4. - P.449-453. https://hrcak.srce.hr/241164

[11] Koizhanova A.K., Kenzhaliyev B.K. Kamalov E.N. Yerdenova M.B., Magomedov D.R., Abdyldayev H.H. Research of gold extraction technology from technogenic raw material // News of the National Academy of Sciences of the Republic of Kazakhstan. Series of Chemistry and technology. - 2020. - №1. - P.95-101. https://doi.org/10.32014/2020.2518-1491.12

[12] Kvyatkovskiy S.A., Kozhakhmetov S.M., Kim L.P., Yesetov U.E., Omirzakov B.A. Development of technology and equipment for direct smelting of refractory ledge gold ores of Teriskey LTD Ore mining company // Kompleksnoe ispol'zovanie mineral'nogo syr’a. - 2016. - №4. - P. 20-24 http://kimsimio.kz/ru/\#iLightbox[gallery-rw-1]/4

[13] Kozhakhmetov S.M., Gemeal A.M.B., Sokolovskaya L.V., Semenova A.S. Studies of smelting products of high-sulfur low-copper concentrates // World of Metallurgy - ERZMETALL. - 2020. - №3. - P. 134140. $\quad$ https://www.gdmbshop.de/epages/79896293.sf/de_DE/?ObjectPath=/ Shops/79896293/Products/WoMet-3-2020

[14] Lennartsson A. Development of a process model for a Peire-Smith converter. SE-97187. Lulea. - 2013. - p.78. https://www.diva-portal.org/smash/get/diva2:998911/FULLTEXT01.pdf

[15] Lennartsson A., Engström F., Björkman B., Samuelsson C. Development of a model for copper converting // Canadian Metallurgical Quarterly. - Vol 52. - 2013. - P.422-429. https://doi.org/10.1179/1879139513Y.0000000089

[16] Kvyatkovskiy S.A., Kozhakhmetov S.M., Sitko E.A., Shukurov B.M., Umirzakov B.A. The possibilities of depletion of copper smelters slag // Modern science. - 2019. - № 8. - Vol. I. - P.218-223. https://elibrary.ru/item.asp?id=39206446

Journal homepage: http://teknomekanik.ppj.unp.ac.id

DOI: https://doi.org/10.24036/teknomekanik.v5i1.11972 
[17] Kozhakhetov S.M., Kvyatkovskiy S.A., Kenzhaliyev É.B., Sokolovskaya L.V., Semenova A.S. Pyrometallurgical Technology for Treatment of High-Sulfur Concentrate Lean with Respect to Copper // Metallurgist. - January 2020. - V. 63, Is. 9-10. - P. 984-992. https://doi.org/10.1007/s11015-02000916-x

[18] Kozhakhmetov S.M., Kvyatkovskiy S.A., Semenova A.S., Baysanov A.S. Investigation of the process of joint melting of copper-rich high-silicon and high-sulfur copper concentrates // Non-ferrous metals. - 2020. - № 8. - P.6-11. https://doi.org/10.17580/tsm.2020.08.01

[19] Kvyatkovskiy S., Gemeal A.M.B., Sitko E. Influence of different factors on the structure of metallurgical slags // World of Metallurgy - ERZMETALL. - 2020. - V. 73. - № 2. - P. 78-82. https://fliphtml5.com/drgc/dzyl/basic

[20] Kvyatkovskiy S.A., Sit'ko E.A., Sukurov B.M., Omirzakov B.A. Effect of Temperature and Amount of Flux in a Charge on Structure and Phase Composition of Balkhash Copper Smelter Plant Slags // Metallurgist. - January 2020. - Vol. 63, - Iss. 9-10. - P.1094-1104. https://doi.org/10.1007/s11015-020$\underline{00927-8}$

[21] Kenzhaliyev B.K., Trebukhov S.A., Volodin V.N., Trebukhov A.A., Tuleutai F.H. Extraction of selenium from industrial products of metallurgical production // Kompleksnoe ispol'zovanie mineral'nogo syr'a. - 2018. - №4. - P.56-64. https://doi.org/10.31643/2018/6445.30

[22] Kenzhaliyev B.K., Trebukhov S.A., Nitsenko A.V., Burabayeva N.M. Extraction of selenium from the dusts of bag dust filters of the Kaldo furnace // International Journal of Mechanical and Production Engineering Research and Development (IJMPERD) - 2020. - Vol. 10, - Iss. 3. - P.547-552. http://www.tjprc.org/view_paper.php?id=12715

[23] Kenzhaliyev B.K., Trebukhov S.A., Nitsenko A.V., Burabayeva N.M., Trebukhov A.A. Determination of technological parameters of the selenium recovery from metallurgical production middlings in a vacuum-distillation unit // International Journal of Mechanical and Production Engineering Research and Development (IJMPERD). - 2019. - Vol. 9-6. - Iss. 6. - P.87-98. http://www.tjprc.org/view_paper.php?id=12051

[24] Abdulvaliyev R.A., Gladyshev S.V., Pozmogov V.A., Kasymzhanova A.K. Hydrochemical technology of processing ferruginous fraction of bauxite // Ore enrichment. - 2019. - №4. - P.44-49. http://www.rudmet.ru/journal/1848/article/31478/

[25] Abdulvaliyev R.A., Gladyshev S.V., Kenzhaliyev B.K., Imangalieva L.M. Complex processing of ferruginous fraction of bauxite to obtain high-grade cast iron // Ore dressing. - 2020. - №2. - P.41-45. https://doi.org/10.17580/or.2020.02.07

[26] Dyussenova S., Kenzhaliyev B., Abdulvaliyev R., Gladyshev S. The method of processing technogenic tailings of chromium // Journal of Mining and Metallurgy, 56 A. 2020. - P.1-6. https://www.jmma.tfbor.bg.ac.rs/accepted-articles/

[27] Gladyshev S.V., Abdulvaliyev R.A., Kenzhaliyev B.K., Dyusenova S.B., Imangalieva L.M. Development of technology for obtaining chromite concentrate from sludge tailings of enrichment // Kompleksnoe ispol'zovanie mineral'nogo syr'a. - 2018. - №1. - P.12-17. http://kims-imio.kz/wpcontent/uploads/2018/05/kims2018-1-14-19.pdf

[28] Lokhova N.G., Naimanbayev M.A., Baltabekova Zh. A., Kasymzhanov K. K. Sorption extraction and concentration of rare earth metals from solutions of extraction phosphoric acid // Kompleksnoe ispol'zovanie mineral'nogo syr’a. - 2018. - №3. - P.62-68. http://kims-imio.kz/wpcontent/uploads/2018/08/\%E2\%84\%963-2018-62-68.pdf

[29] Baltabekova Zh.A., Kenzhaliyev B.K., Lokhova N.G. Sorption Extraction of Rare-Earth Elements and Iron from Acid Solutions // International Journal of Advanced Science and Technology. - 2020. - 29(04). - P. 2539-2550. http://sersc.org/journals/index.php/IJAST/article/view/21098/10670

[30] Lokhova, N.G., Baltabekova, Z.A., Naimanbayev, M.A., Yessengaziyev, A.A., Kassymzhanov, K.K. Extraction of rare-earth metals from zircon concentration tailings // International Journal of Advanced Science and Technology. - 2020. - V. 29, - Iss. 9s. - P. 893-899. http://sersc.org/journals/index.php/IJAST/issue/view/282 
[31] Kenzhaliyev, B.K., Lokhova, N.G., Kvyatkovskaya, M.N., Baltabekova, Z.A. Thermal analysis for determination of individual rem phases in industrial middling product // International Journal of Advanced Science and Technology. - 2020. - V 29, - Iss. 7s. - P. 1-7. http://sersc.org/journals/index.php/IJAST/issue/view/277

[32] Abdulvaliyev R.A., Gladyshev S.V., Akhmadieva N.K., Imangalieva L.M. Extraction of REE from red sludge by the method of reducing melting // Ore enrichment.- 2019. - № 3. - C. 49-54. https://doi.org/10.17580/or.2019.03.08

[33] Pozmogov V.A., Kuldeev E.I., Dorofeev D.V., Imangalieva L.M., Kvyatkovskaya M.L. Determination of physico-chemical properties and phase composition of ferruginous sands of alumina production to find ways of their further processing // Kompleksnoe ispol'zovanie mineral’nogo syr'a. - 2018. - №3. - P.69-77. http://kims-imio.kz/wp-content/uploads/2018/08/\%E2\%84\%963-2018-69-77.pdf

[34] Abdulvaliyev R.A., Akhmadeeva N.K., Gladyshev S.V., Imangalieva L.M., Manapova A.I. Restorative melting of modified red sludge // Kompleksnoe ispol'zovanie mineral'nogo syr'a. - 2018. - № 3. P.15-20. https://doi.org/10.31643/2018/6445.12

[35] Abdulvaliyev R.A., Gladyshev S.V., Kenzhaliyev B.K., Akhmadieva N.K., Imangalieva L.M., Kasymzhanova A.K. Processing of the red sludge of the Turkish alumina plant with the extraction of gallium, vanadium and the production of iron oxide pigments // Chemical Technology. - 2020. - №1. P.24-29. https://www.elibrary.ru/item.asp?id=41800911

[36] Mamaeva A.A.; Panichkin A.V.; Kenzhegulov A.K.; Kshibekova B.B. (2021). Deposition of a titanium carbonitride coating by magnetron sputtering on a substrate with a potential voltage. Challenges of Science. Issue IV, 2021, pp. 103-108. https://doi.org/10.31643/2021.16

[37] Abdulvaliyev R.A., Gladyshev S.V., Kenzhaliyev B.K., L. Imangalieva.M. Complex of processing of iron-containing bauxites from the manufacture of precious iron // Ore enrichment. - 2020. - №2. https://doi.org/17580/or.2020.02.07 